\title{
Researching translation and interpreting in non-governmental organisations
}

Article

Accepted Version

Tesseur, W. (2018) Researching translation and interpreting in non-governmental organisations. Translation and Interpreting in Non-Governmental Organisations, 7 (1). pp. 1-19. ISSN 2211-372X doi: https://doi.org/10.1075/ts.00001.tes Available at https://centaur.reading.ac.uk/78747/

It is advisable to refer to the publisher's version if you intend to cite from the work. See Guidance on citing.

To link to this article DOI: http://dx.doi.org/10.1075/ts.00001.tes

Publisher: John Benjamins Publishing Company

All outputs in CentAUR are protected by Intellectual Property Rights law, including copyright law. Copyright and IPR is retained by the creators or other copyright holders. Terms and conditions for use of this material are defined in the End User Agreement.

\section{www.reading.ac.uk/centaur}

\section{CentAUR}

Central Archive at the University of Reading

Reading's research outputs online 
This is the author accepted manuscript of the article by Wine Tesseur (2018) 'Researching translation and interpreting in Non-Governmental Organisations', Translation Spaces 7(1): 1-19, which has been published in final form at https://doi.org/10.1075/ts.00001.tes. This article is under copyright and the publisher should be contacted for permission to re-use or reprint the material in any form.

\title{
Researching translation and interpreting in Non-Governmental Organisations
}

Wine Tesseur, University of Reading

\begin{abstract}
Non-governmental organisations hold an important place in today's globalised society. After presenting an overview of previous research on Translation and Interpreting Studies on language mediation in NGOs, this introduction to the special issue argues that more research into NGOs' translation and interpreting practices and policies is required to better understand these organisations and their influence on global society. The introduction engages with what NGO practitioners and professional translators have said on current challenges in translating and interpreting in the context of NGOs, and what this implies for future research and training in Translation and Interpreting Studies. Lastly, it reflects on the use of interdisciplinary approaches to understanding NGOs as global organisations and discusses the contribution that Translation and Interpreting Studies could make to other disciplines that aim to gain new insights on these organisations.
\end{abstract}

Keywords: NGOs, development, humanitarian aid, interdisciplinarity, intersectoral collaboration

\section{Introduction}

The second half of the twentieth century has been marked by a shift from national to global governance, with a large number of non-governmental and supranational organisations being founded. Non-governmental organisations (NGOs) ranging from Amnesty International and Oxfam to Save the Children and Greenpeace have become powerful players that promote, regulate and intervene in global politics and common affairs of humanity (McGrew and Held 2002). NGOs exercise various important roles in today's globalised society: as global workplaces in the new information- and knowledge-based economy (Castells 2000); as organisations that seek to influence global political decisions; and as providers of humanitarian and development assistance. They have expanded both their scope and range of activities over the past few decades, and many NGOs work across linguistic and national borders. In addition, a number of these organisations provide assistance to refugees, asylum seekers and local communities in emergency and crisis situations. In all of these contexts, speakers from a wide range of languages come together, and providing language mediation often 
This is the author accepted manuscript of the article by Wine Tesseur (2018) 'Researching translation and interpreting in Non-Governmental Organisations', Translation Spaces 7(1): 1-19, which has been published in final form at https://doi.org/10.1075/ts.00001.tes. This article is under copyright and the publisher should be contacted for permission to re-use or reprint the material in any form.

forms part of NGOs' day-to-day work. In other words, translation and interpreting are key to the functioning of these organisations, as they negotiate and interact between actors from a wide variety of cultural and linguistic backgrounds in the work they conduct.

This special issue focuses on translation and interpreting practices and policies in NGOs. The contributors explore a range of organisations, languages and geographical settings, drawing on a variety of theoretical and methodological approaches. In addition, the special issue aims to engage with practitioners, scholars and viewpoints from other disciplines, in order to reflect on the multidisciplinary and intersectoral approaches capable of enhancing our understanding of translation in the NGO sector. From its inception, Translation Spaces has sought to bring form to a more concrete engagement between Translation Studies and other disciplines, and thus this journal is the perfect platform to present these different points of view.

The special issue draws on contributions to the 'Translating Development' seminar, which took place at the Institute of Modern Languages Research (IMLR, University of London) on 12 October 2017. The seminar was organised as part of the UK-based research project 'The Listening Zones of NGOs: Languages and Cultural Knowledge in Development Programmes', funded by the Arts and Humanities Research Council. It brought together professional translators from NGOs, translation studies scholars, freelance translators and interpreters, as well as NGO development workers. ${ }^{1}$ Some of the articles in this special issue draw on the practitioner contributions and the ensuing interdisciplinary and intersectoral debates that took place during this stimulating day of discussions.

This introduction to the special issue seeks to tease out what the current gaps and needs are in research on translation in NGOs. It first identifies gaps in our current knowledge and understanding of language and translation practices in NGOs, and then articulates why research on translation in NGOs is needed. Drawing on the rich discussions that materialized during the 'Translating Development' seminar, we discuss possible implications for training and research on translation in NGOs. Finally, we briefly describe the aims and contents of this special issue.

\section{Gaps in current research on NGOs, languages and translation}

Before being able to discuss research to date on translation and interpreting in NGOs, we should specify what we mean by non-governmental organisations. Defining the term has been problematic ever since it was first used by the United Nations in its Charter in 1945. Article 71 of the UN's Charter made arrangements for representatives to the UN and made a distinction between 'specialised

\footnotetext{
${ }^{1}$ Visit the project website on http://www.reading.ac.uk/listening-zones-ngos for more information on the seminar and to watch the recording of Panel 1 with practitioner contributions from Family for Every Child, Oxfam GB, Save the Children UK, and a freelance translator who works with several NGOs.
} 
This is the author accepted manuscript of the article by Wine Tesseur (2018) 'Researching translation and interpreting in Non-Governmental Organisations', Translation Spaces 7(1): 1-19, which has been published in final form at https://doi.org/10.1075/ts.00001.tes. This article is under copyright and the publisher should be contacted for permission to re-use or reprint the material in any form.

agencies', such as the World Health Organisation (WHO), which had the higher status of 'participation without vote', and other agencies which were considered as having lower status that only consisted of 'consultation'. These agencies were referred to as 'non-governmental organisations', yet the term was left undefined. Willetts (2011: 7) notes that the term did not move outside the world of diplomacy until the 1970s. However, nowadays, the term is widely used in public debate and social life, and it is not so well known that 'NGOs' originated as a rather vague and broad term from the UN Charter.

As understanding of the term has grown, the number of organisations that are registered as NGOs has also increased exponentially, with the Yearbook of International Organisations counting 59,383 NGOs versus 7,756 International Organisations (IGOs) in 2014-2015 (Union of International Associations 2014). Although citing numbers like these as a way of claiming that there has been an 'unprecedented rise' of international NGOs has been contested and described as an interpretation of transnational civil society based on a limited view of the phenomenon (Davies 2014), what these numbers do show is the widespread existence of these organisations throughout the world in today's society. Therefore, as a global phenomenon of agents taking collective action that transcends national and/or linguistic boundaries, NGOs merit scholarly investigation from Translation and Interpreting Studies (TIS).

Our intention in this special issue is to start mapping translation and interpreting activities in a sector that has remained largely overlooked. Thus, we here interpret the term 'NGO' in a broad way that intends to distinguish it from other types of organisations such as intergovernmental organisations, like the EU and the UN, and multinational companies, which are characterised by a different work ethos. For the purposes of this special issue, we define NGOs as organisations that share the following characteristics (in accordance with Willetts 2011):

- Organisations that are non-profit-making or not engaged in commercial activities;

- Organisations that are independent from governments, or that can be defined as 'hybrid' organisations, such as the Red Cross;

- Established organisations, thus excluding ephemeral groups, informal associations, and unstructured networks

In addition, our focus in this special issue is on organisations that work internationally. These are either international NGOs (INGOs) who have members in various countries, such as Amnesty International, or NGOs that work in global partnership with organisations in developing countries, such as Caritas Switzerland (see Carmen Delgado Luchner's contribution in this special issue). 
This is the author accepted manuscript of the article by Wine Tesseur (2018) 'Researching translation and interpreting in Non-Governmental Organisations', Translation Spaces 7(1): 1-19, which has been published in final form at https://doi.org/10.1075/ts.00001.tes. This article is under copyright and the publisher should be contacted for permission to re-use or reprint the material in any form.

Studies on NGOs are well at home in TIS research that has emphasised the role of the socio-political context in which translations are produced. Since the early 2000s, scholars have increasingly considered translation and interpreting as sociological acts, in which language mediators make decisions depending on their social, political, and ethical positions and the institutional context in which they are working. The factors that have an impact on meaning-making become particularly important when considering translation in concrete institutions, where translators are subordinate to the overall aims of the institution and the intra-institutional procedures (Koskinen 2008: 18). Research on institutional translation has thus far covered a wide variety of institutions, including news agencies, publishing companies, as well as supra-national organisations (Cao and Zhao 2008; Kang 2014; Koskinen 2008; Schäffner 2001; Tosi 2003; Tcaciuc and Mackevic 2017). Non-governmental organisations have been covered to some extent, but an overview on research conducted in this area remains inevitably short. National NGOs in the Spanish context have been the object of research in studies such as Arranz de la Torre (2001), which has analysed textual features of documents produced by an NGO providing cancer care in Spain, and Valero Garcés and Cata (2006), which has dealt with volunteer translation and interpreting services offered through Spanish NGOs that provide assistance to immigrants and asylum seekers. In the UK context, international NGOs such as Amnesty International (Schäffner, Tcaciuc, and Tesseur 2014; Tesseur 2014, 2017b) and Oxfam GB (Footitt 2017; Lehtovaara 2009) have attracted some attention. In the context of growing globalisation, publications such as Guillaume (2010) and Guidère $(2010,2011)$ have aimed to provide general insights into how NGOs may deal with communication needs. This work has been based on theoretical reflections and has been mostly prescriptive. Hence, there is but little understanding in TIS at the moment of translation and interpreting policies and practices in (international) NGOs, and a lack of in-depth case studies on how specific NGOs may deal with their language needs.

Because NGOs work in highly multilingual contexts, it is remarkable that TIS has only paid scant attention to these translating institutions. This gap perhaps is related to the fact that translation and interpreting for NGOs have been widely associated with volunteering. Pym (2008: 77) notes that NGOs "rarely have the funding necessary for symbolic translation practices; their use of translation is closer to what might precariously be termed 'real needs', they are far less likely to employ in-house staff translators or interpreters". In line with this assumption, NGOs have mostly been discussed in TIS in the context of volunteer and activist translation. For example, some studies have focused on contemporary activist translator and interpreting groups, such as Babels and ECOS (Baker 2006; Baker 2009; Boéri and Maier 2010; Gambier 2007). This research has foregrounded the role of volunteer translators and interpreters as agents, or has focused on activist networks, rather than on the NGOs as institutions, which may or may not rely on these services. Recent years have also seen a surge in studies exploring the many forms of Non-Professional Interpreting and Translation (NPIT) 
This is the author accepted manuscript of the article by Wine Tesseur (2018) 'Researching translation and interpreting in Non-Governmental Organisations', Translation Spaces 7(1): 1-19, which has been published in final form at https://doi.org/10.1075/ts.00001.tes. This article is under copyright and the publisher should be contacted for permission to re-use or reprint the material in any form.

(Antonini et al. 2017; Evrin and Meyer 2016; Pérez-González and Susam-Saraeva 2012), as well as of community translation and interpreting (Schäffner, Kredens, and Fowler 2013; Taibi and Ozolins 2016; Valero-Garcés and Tipton 2017). Some of this research has touched on the contexts in which NGOs work (see e.g. Tipton 2017), yet systematic studies of NGOs' translation and interpreting practices have remained lacking.

The role of languages and translation in NGOs has not only escaped attention in Translation Studies: disciplines that take NGOs as their object of research, such as International Relations and Development Studies, have also largely remained silent on languages. Fierke (2003: 67) has argued that a "history of silence has marked the issue of language in IR". The silence in IR is understood as having come from "a disciplinary quest that consists of turning International Relations into an objective science", which has led to "the dismissal of the messy language of politics and human values. Like the subject of natural science, the subjects of political analysis are presumed to be mute, leaving the scientist with a monopoly on concept formation" (2003: 67). In Development Studies too, whilst the role of interpreters is sometimes mentioned as a part of information and data collection (Bujra 2006), languages and translation scarcely feature within the general literature on NGO organisational management. They are absent in key texts such as Fowler and Malunga (2010), or Lewis (2014), and Suzuki (1998) devotes only a small section to them in a study of relationships between NGOs' headquarters and field offices.

Nevertheless, NGOs play a key role in enhancing communication, providing access to information and advocating for and on behalf of the people they work with. Dijkzeul has described NGOs as "transnational organisations pur sang", who operate "in various localities [...] in a decentralised manner through their activities [...] in, above, and between traditional 'container spaces' of national societies" (2008: 80). The actors that NGOs work with not only include local communities, often referred to as NGOs' beneficiaries, but also local partner organisations and national NGOs, local and national governments, donors, and other international organisations. Understanding NGOs' translation and interpreting practices would provide crucial insights into their role as mediators between these different actors, and into how their communicative practices and efforts of translation and interpreting help them to achieve their aims.

\section{Why do we need research on NGOs, and why now?}

This special issue stems from an acknowledgement that NGOs are powerful transnational political players, whose linguistic practices in working across borders have been but marginally investigated in Translation and Interpreting Studies. A number of shifts in the NGO and translation sector in light of globalisation make this a crucial area for more in-depth research. 
This is the author accepted manuscript of the article by Wine Tesseur (2018) 'Researching translation and interpreting in Non-Governmental Organisations', Translation Spaces 7(1): 1-19, which has been published in final form at https://doi.org/10.1075/ts.00001.tes. This article is under copyright and the publisher should be contacted for permission to re-use or reprint the material in any form.

Firstly, the effect of global changes both in the NGO and translation sectors have been widely recognised and discussed. The rise of the internet and the rapid development of machine translation and other translation software have transformed the translator's profession and the nature of translation work. Whereas the effects of these changes have been elucidated in the context of supranational organisations (e.g. as in Cronin 2003), NGOs have not benefitted from the same attention. Yet NGOs have also been part of the shift to network and knowledge societies (Castells 2000). The nature of knowledge and information are central in the NGO sector and merit attention from TIS scholars. NGOs have played an important role in developing and employing new information technologies. Willetts (2011: 84-113) describes that the desire amongst NGOs for networking has enhanced global communications, with NGOs being the first to offer electronic communications to the general public and to promote connections between newly emerging networks. Moreover, the interest of NGOs in information technology is inherently linked to the idea that it is a lack of knowledge that may prevent countries in the global South from developing, a premise that has gained momentum over the last decade or so in the NGO sector. The transformation in approaches to development that foreground knowledge have been crystallised in the World Bank's 'knowledge-fordevelopment' strategies in 1998 (World Bank 1998), and the emphasis on knowledge has continued to grow in the sector at large. This is illustrated for example by the responses from international UKbased NGOs that participated in a survey conducted by Bond, a UK network for international development NGOs. In the survey, INGOs described their future role in the development sector exactly in the area of knowledge and information: INGOs have "deep wells of evidence and experience to share", with which they can support partners in the Global South (Bond 2015a). Recent efforts among practitioners and academics have further explored the nature of knowledge in a global context in which INGOs would become spaces "for expert knowledge creation" and "effective knowledge-management systems" (Hayman et al. 2016: 2). This change to NGOs as "knowledge hubs' can also be linked to the recent organisational changes that many international, Northern-based NGOs have gone through, in order to ensure they remain relevant in today's international development context. In an effort to become 'truly global' organisations (e.g. Amnesty International UK 2013; Byanyima 2015; Moorehead and Clark 2015), a number of NGOs have clustered into federations, associations, 'families', and international networks (e.g. CARE International, Oxfam International, Save the Children International, Family for Every Child). This type of change has often gone hand in hand with tasks from traditionally Northern-based headquarters being decentralised to the Global East and South (Bond 2015b; Smedley 2014). Exploring translation and interpreting in these organisations, many of which are aiming to be 'truly global', is thus a way of capturing some of the phenomena brought about by globalisation (Tesseur 2017a). Research on NGOs would shed more light on the role of multilingualism, language and translation policy in the field of transnational civil 
This is the author accepted manuscript of the article by Wine Tesseur (2018) 'Researching translation and interpreting in Non-Governmental Organisations', Translation Spaces 7(1): 1-19, which has been published in final form at https://doi.org/10.1075/ts.00001.tes. This article is under copyright and the publisher should be contacted for permission to re-use or reprint the material in any form.

society, and would help us understand the role of NGOs as providers and users of information and knowledge across national and linguistic borders. At the same time, this type of research would support NGOs in understanding their needs better, something NGO workers themselves have indicated the importance of (Crack 2014; Tesseur 2015).

Secondly, research in translation in NGOs is particularly timely because of NGOs' key role in delivering the UN's Sustainable Development Goals (SDGs). The 17 global goals, adopted by all 193 UN member states, aim to put the most vulnerable first and to leave no one behind (United Nations 2015). Although this implies communicating in a multiplicity of languages, the SDGs are silent on language issues. Proponents see sustainable development as emerging from dialogue with local communities (Bass and Dalal-Clayton 2002; McCall 2011), yet it is unclear how sustainable, two-way democratic communication will be ensured. The absence of any mention of languages in the SDGs has recently attracted critical attention, with three international conferences having been organised on this topic over the last two years: the British Council's 12th conference on Language and Development, which focused on 'Languages and the Sustainable Development Goals' (Dakar, November 2017), and two international symposia organised by the Study Group on Language and the UN. ${ }^{2}$ The fact that academics and practitioners are drawing attention to the role of languages in delivering the SDGs is an important development. However, it should be noted that an overwhelming majority of contributions to these conferences has focused on language and the SDGs in the context of education, discussing issues of literary and mother-tongue education for refugees, migrants and other language minority groups. Much of the input has thus come from English language and education departments, and contributions from the field of Translation and Interpreting Studies have remained limited. We argue here that it is time for TIS to join in this intersectoral and interdisciplinary debate. The achievement of the Sustainable Development Goals is an incredibly ambitious intercultural and multilingual venture, in which the countries of the world are working together in partnership. We argue here that it should be one of TIS's key tasks as a discipline to point out the central role of translation and interpreting in bringing this global mission to a successful end.

Thirdly, the NGO sector has been labelled as being in 'crisis' for over a decade (see e.g. McGann and Johnstone 2005), and questions on NGOs' credibility and legitimacy have repeatedly been raised. The recent Oxfam sexual exploitation scandal has put the issue of accountability at the forefront of NGOs' and donors' agendas, and it has been widely discussed in the media, by academics and the sector (Crack 2018; Carolei 2018; Hilhorst 2018). These debates on sexual exploitation and safeguarding measures feed directly into discussions on how to increase 'downward' accountability to beneficiaries

\footnotetext{
2 'Language and the Sustainable Development Goals', United Nations Plaza, New York, May 2016; and 'Languages, the Sustainable Development Goals, and Vulnerable Populations', United Nations Plaza, New York, May 2017.
} 
This is the author accepted manuscript of the article by Wine Tesseur (2018) 'Researching translation and interpreting in Non-Governmental Organisations', Translation Spaces 7(1): 1-19, which has been published in final form at https://doi.org/10.1075/ts.00001.tes. This article is under copyright and the publisher should be contacted for permission to re-use or reprint the material in any form.

and local communities, aiming to redress the overwhelming focus on 'upward' accountability to donors (Banks, Hulme, and Edwards 2015; Crack 2013). Despite the shift to 'participatory approaches' to development from the 1980s onwards (see e.g. the seminal work of Chambers (1983, 1997)), concerns have been raised that unequal power relationships continue to shape the aid agenda and how development is 'done'. The models and procedures used by donors, who hold the pursestrings, continue to have a major effect on how development is shaped on the ground. As noted by Wallace et al. (2007: 162),

There is an almost invisible and little analysed bias towards valuing and favouring the systems, documentation and approaches that are developed in the north and are only really accessible to the top-level staff in the south. The accompanying detailed explanations, models and practices privilege these approaches over the local knowledge, concepts, language ability and understanding of civil society of staff and local organizations in the south which are often verbally communicated and hard to capture in a system that relies so heavily on documentation.

Issues of accountability, power, building relationships of trust, and respecting local communities and their cultures, which have all come up in relation to the recent Oxfam crisis, are thus far from resolved, and a deeper engagement of TIS with issues of translating knowledge and 'development' could be highly insightful in these debates. Furthermore, next to the criticism levelled at international NGOs for their practices with their legitimacy questioned, there is the more general phenomenon of a shrinking space for civil society. Governments all over the world are increasingly using laws and regulations to restrict organisations from registering, protesting and accessing funds. In its 2017 State of Civil Society Report, CIVICUS referred to this situation as a 'global emergency' of civic space, in which civil society activists and organisations are increasingly under attack with restrictive measures including detentions, arrest and extrajudicial killings, and freedom of expression being applied selectively (CIVICUS 2017). In this context of 'crisis', NGOs, particularly those large international NGOs from Northern countries discussed in this special issue, need to ask themselves questions on how they will support local NGOs and civil society organisations in working towards the improvement of people's lives, by tackling poverty and enhancing human rights. Within these debates and discussions, there is a space for TIS to support NGOs in achieving these aims and envisaging accountable ways of working that are respectful towards the cultures and languages of those they work with.

\section{On this special issue}


This is the author accepted manuscript of the article by Wine Tesseur (2018) 'Researching translation and interpreting in Non-Governmental Organisations', Translation Spaces 7(1): 1-19, which has been published in final form at https://doi.org/10.1075/ts.00001.tes. This article is under copyright and the publisher should be contacted for permission to re-use or reprint the material in any form.

This special issue set out to contribute to Translation and Interpreting Studies in two ways: (1) by mapping translation and interpreting practices in NGOs, covering a wide variety of geographical locations, thematic areas, languages and organisations; and (2) by opening up the discussion on translation and interpreting in NGOs to an interdisciplinary mix of contributors, drawn both from practitioners working for NGOs and from colleagues from related disciplines with an interest in languages and NGOs. It thus aims to revisit the initial aim of the journal of Translation Spaces to bring form to a more concrete engagement between Translation and Interpreting Studies and other disciplines, in light of globalisation and powerful technological advances.

The special issue is split into three main parts: academic papers (contributions 1-3); papers by practitioners (contributions 4-5); and interdisciplinary discussions (contributions 6-7). The aim of the contributors can be described as an attempt to shed light in a more systematic way on current language and translation needs, practices and solutions in NGOs. The various contributions highlight what current problems may exist, what good practice looks like or could look like, and what further training or research needs should be addressed to overcome existing difficulties.

The papers cover an array of organisations, including Amnesty International (Hawker; Combeaud Bonallack), Caritas Switzerland, the Fédération genevoise de cooperation (Delgado Luchner), the New Zealand Red Cross (Federici and Cadwell), and Oxfam GB (Sanz Martins). In addition, the special issue contains an interdisciplinary discussion between a translation researcher, an international communications specialist, and a development practitioner (Hamaidia, Methven and Woodin); as well as a reflective piece by Moreno Rivero on what various shapes interdisciplinary collaboration can take in investigating multilingual practices in NGOs. His contribution is based on two interviews: one with Dr Alexa Koenig (Executive Director of the Human Rights Center, UC Berkeley School of Law) on the Human Rights Investigations Lab; and one with Dr Nada Ghandour-Demiri (Visiting Assistant Professor of Sociology at American University of Beirut), who reflects on a joint research project she was involved in with Translators Without Borders and Save the Children on language and comprehension barriers in Greece's migration crisis (Ghandour-Demiri 2017). The purpose of these interdisciplinary discussions is to explore what the role of Translation and Interpreting Studies is and/or could be in contributing to research and training efforts that could cross disciplinary and sectoral boundaries relating to language, translation, interpreting and NGOs.

Despite the intention in the Call for Papers for this special issue to attract papers on any kind of NGO that would fit into the broad definition provided above, including for example NGOs whose activities may focus on the environment (e.g. Greenpeace), sport (e.g. the Fédération Internationale de Football Association) or professions (e.g. the International Federation of Accountants; see Davies 2014 for a description of the wide variety of activities that NGOs cover), or small, local NGOs who may have 
This is the author accepted manuscript of the article by Wine Tesseur (2018) 'Researching translation and interpreting in Non-Governmental Organisations', Translation Spaces 7(1): 1-19, which has been published in final form at https://doi.org/10.1075/ts.00001.tes. This article is under copyright and the publisher should be contacted for permission to re-use or reprint the material in any form.

translation needs in their work because of the people they work with, the case studies in this special issue have remained limited to large international NGOs from the North that are involved in advocacy and service provision that addresses issues of poverty and humanitarian need. While this may be seen as a shortcoming, it has also lead to a special issue in which common themes arise in discussions from all contributors.

One of these themes is the need to contextualise our understanding of translation and interpreting practices in NGOs. Both academic and practitioner contributions reveal that practices vary depending on the specific actors involved, location, languages, resources, etc. Furthermore, the case studies confirm the argument put forward by researchers such as Footitt and Kelly (2012) and Meylaerts (2017), i.e. that it does not suffice to study only institutional policies on language and translation (if they exist at all) to obtain a realistic picture of translation and interpreting practices in these complex multilingual contexts. For example, Nancy Hawker's contribution follows the trajectory of an Amnesty 'text' or testimony from its first inception to the final product that is presented to audiences and reveals the many forms of translation that such a text goes through. These far transcend the process of professional translation in Amnesty's Language Resource Centre, as described previously in Tesseur $(2014,2017 \mathrm{a})$, and include processes of digitalisation and translation of forms of spoken Arabic into written Modern Standard Arabic and English by Amnesty researchers. Carmen Delgado Luchner's contribution equally shows that approaches to languages and translation are not standardised in NGOs. From her data, an intriguing picture emerges in which language is one of the factors that influence NGO structure and decision-making. From their experience as translation practitioners working in NGOs, Alberto Sanz Martins (Oxfam GB) and Patricia Combeaud Bonallack (Amnesty International) describe language and translation policies and practices in their organisations, and equally show that these greatly differ depending on the languages involved. Both contributions also present the complex and changing picture of translation needs in the context of changing organisational structures.

Another recurring theme in all contributions is power distribution between the different actors involved in NGO work and the NGOs as institutions. The ability to speak multiple languages as well as the availability of translation are described by some contributors as forms of empowerment. For example, Federico Federici and Patrick Cadwell in their contribution describe how training citizen translators can enhance communities' resilience. Echoing arguments put forward by Taibi and Ozolins (2016) in the context of community translation, Federici and Cadwell argue that citizen Translators "may represent a way of empowering vulnerable communities". In Nancy Hawker's contribution, the process of collecting, translating and presenting testimony of human rights abuses is described as one that can empower witnesses, despite the many transformations the original words of a witness may go 
This is the author accepted manuscript of the article by Wine Tesseur (2018) 'Researching translation and interpreting in Non-Governmental Organisations', Translation Spaces 7(1): 1-19, which has been published in final form at https://doi.org/10.1075/ts.00001.tes. This article is under copyright and the publisher should be contacted for permission to re-use or reprint the material in any form.

through. In Hawker's words, the point is not to uncover "a tortuous opaque game of 'Chinese whispers", since "testimonies were always going to be co-produced and iterated". Rather, "recognising the mediator's - whether the researcher or the translator's - agency in bearing that responsibility is what gives the publication of human rights testimonies the potential to redress testimonial injustice". From her side, Carmen Delgado Luchner uncovers a whole different way of empowering people, which is not about making voices heard, as so effectively advocated for in the practitioner papers by Alberto Sanz Martins and Patricia Combeaud Bonallack, but is about how not speaking a language can enable empowerment of others. Delgado Luchner reveals that some Northern-based NGOs in her research data "consider their lack of mastery of the local languages spoken by beneficiaries $[\ldots]$ as conducive to strengthening the independence of the Southern partner NGO and ultimately of beneficiaries themselves", because language barriers can "put a natural limit on their ability to interfere in the local implementation of a project". The complexities of dependencies because of language barriers that Delgado Luchner reveals draw into question established models of development work that represent international aid as a chain in which power is solely held by donors because they hold the purse strings. Her contribution clearly reveals the added value Translation and Interpreting research could make to disciplines such as Development Studies and International Relations.

A theme that emerges from all contributions is the enormous amount of non-professional translation and interpreting practices that take place in the context of NGO work. Contributions such as those of Lena Hamaidia, Sarah Methven and Jane Woodin, Javier Moreno-Rivero, and Carmen Delgado Luchner point to the massive contribution that bilingual or multilingual NGO workers make to development and humanitarian endeavours by translating and interpreting ideas, texts, and ways of working as part of their day to day work. Equally, Nancy Hawker's contribution shows how translation is an intrinsic part of collecting, entextualising and publishing human rights testimonies as part of Amnesty's work. Perhaps uncovering the informal practices is one of the most important contributions of this special issue: it forms a first important step in addressing Translation Studies' overdependence on literary texts and contexts of professional translation that Marais (2014) has previously drawn attention to in his effort to bring together Translation Theory and Development Studies. The contributions are much in line with his vision that placing translation "in the broader quest for developing a society" allows us to situate translation "as a factor in the political economy of the day, the day-to-day efforts of people to adapt to the power configurations within which they were born or had been forced" (2014: 7). The findings on the enormous amount of informal translation and interpreting practice in NGOs raises the need to reflect more deeply on what then, exactly, the role of professional translators and interpreters is or should be, and by extension, that of Translation and Interpreting Studies. 
This is the author accepted manuscript of the article by Wine Tesseur (2018) 'Researching translation and interpreting in Non-Governmental Organisations', Translation Spaces 7(1): 1-19, which has been published in final form at https://doi.org/10.1075/ts.00001.tes. This article is under copyright and the publisher should be contacted for permission to re-use or reprint the material in any form.

\section{Implications for Translation and Interpreting Studies research}

Drawing on ideas and arguments presented by contributors to this special issue as well as to the 'Translating Development' seminar mentioned above (12 October 2017, IMLR, London), we here reflect on what we have learned so far on translation and interpreting in NGOs, and the possible implications of these new insights for Translation and Interpreting Studies. In this special issue, translation practitioners have contributed to enhancing our understanding of current institutional translation practices in NGOs, i.e. they have made clear to what extent translation has been institutionalised through policies and practices, such as identifying strategic languages and recruiting additional in-house staff and freelancers to work with NGOs on the translation of organisational documents. But the efforts in this special issue have gone much further than presenting and investigating institutionalised translation practice only. The academic contributions in particular have demonstrated that even in cases where translation practice has remained uninstitutionalised and is mainly dealt with in an informal, unregulated way, translation and interpreting play a key role in making the activities of NGOs a success. The need for more robust data on the key role of translation and interpreting in NGOs' endeavours is one that has emerged strongly from the majority of contributions to this special issue as well as during the 'Translating Development' seminar. This point emerged from a number of observations, such as:

- The fact that translation and interpreting needs are often not taken into account when planning projects in NGOs:

- Translation practitioners indicated translation and interpreting needs are often overlooked in budgets;

- Development and humanitarian workers indicated that translation and interpreting, as well as wider communication needs, are often not part of Monitoring and Evaluation processes;

- Translation practitioners indicated that feedback processes on translation and interpreting provided by internal language services in the NGO are not built in.

- These gaps in internal working policies and practices were seen as leading to a continuous lack of resources for translation and interpreting, i.e. a lack of budget to produce the necessary translations and provide interpreting; and a lack of budget to keep translation software updated with the latest technological developments.

- The amount of time required for professional translation and the reason why a professional language service is important were seen by internal translators as issues that were commonly ill understood by their colleague NGO workers, and these thus presented further challenges to provide the necessary language support. 
This is the author accepted manuscript of the article by Wine Tesseur (2018) 'Researching translation and interpreting in Non-Governmental Organisations', Translation Spaces 7(1): 1-19, which has been published in final form at https://doi.org/10.1075/ts.00001.tes. This article is under copyright and the publisher should be contacted for permission to re-use or reprint the material in any form.

Leading on from these observations, suggestions on future research needs included, amongst others:

- A closer involvement of academic researchers in designing systematic and robust methodological approaches to assess the changing linguistic needs of NGOs on a regular basis;

- A closer involvement of academic researchers in developing widely accessible multilingual terminology databases, and measuring their subsequent impact;

- A need for translation researchers to overtly challenge the dichotomy between professional and volunteer translation;

- A need for translation researchers to emphasise that professional translators have a role to play in enabling and supporting lay interpreting and translation.

- A need for translation researchers to provide evidence of the value of NGO workers' language skills in day to day work, so that these skills can start to be considered as part of NGOs' and local communities' capacity building.

Whilst some of these points are already starting to be addressed, including in this special issue, more remains to be done to enhance our understanding of the role of languages, translation and interpreting in NGOs and to address the needs raised by this vital sector in today's global society. An important future step in Translation and Interpreting Studies research will be to add case studies on other actors in civil society and to overcome the limited point of view presented in this special issue, i.e. that of international, Northern-based NGOs. Studies on if and how translating in the context of NGOs can work as a tool for empowering local communities and citizens should include the experiences of other actors, particularly those working in the Global South, and of those working with far fewer resources than INGOs.

\section{Implications for interdisciplinary approaches to translation and interpreting in NGOs}

Since this special issue makes an explicit effort to engage in interdisciplinary discussions and debates, it is not more than natural to finish this introduction by reflecting on what research on translation and interpreting in NGOs can bring to other disciplines, and what TIS can learn from others.

The points of view presented by Alexa Koenig and Nada Ghandour-Demiri in Javier Moreno-Rivero's contribution resonate with some of the very reasons why the journal of Translation Spaces has aimed to engage in interdisciplinary debate, i.e. the huge role that translation technology and software plays (or can play) in globalised society, and in this case, in the NGO sector. The discussion between Lena Hamaidia, Sarah Methven and Jane Woodin furthermore points to the need for interdisciplinary approaches that will allow us to better understand the work that development NGOs and aid workers engage in. In particular, they emphasise the need for TIS to engage more deeply in discussions on the 'translatability' of key development terms, arguing that the meaning of terms like 'advocacy' is 
This is the author accepted manuscript of the article by Wine Tesseur (2018) 'Researching translation and interpreting in Non-Governmental Organisations', Translation Spaces 7(1): 1-19, which has been published in final form at https://doi.org/10.1075/ts.00001.tes. This article is under copyright and the publisher should be contacted for permission to re-use or reprint the material in any form.

heavily embedded on the local context and culture, a point echoed in work by development practitioners and researchers such as Cornwall and Eade (2010) and Maclean (2007).

At a point in time when interdisciplinary research is given preference to in order to investigate 'real world' problems and to produce outputs that are of social, technical and policy relevance (Rampton, Maybin, and Roberts 2015), it seems pertinent for TIS to establish links with other disciplines that take NGOs and their ways of working as their object of study. For example, the problems touched upon by Hamaidia, Methven and Woodin resonate with the very relevant work of colleagues working in anthropology, law and sociology, such as Gal, Kowalski and Moore (2015), Holcombe (2015), Merry (2006), and Merry and Wood (2015), who have problematised the idea of 'translating' human rights between global and local levels of government. Defining the very notion of translation has been an important part of these endeavours (Gal, Kowalski, and Moore 2015; Merry and Wood 2015), but what has remained lacking is any kind of overt link with research in TIS and with the role of professional translators or interpreters. For example, Merry's hugely insightful work describes "[i]ntermediaries such as community leaders, nongovernmental organization participants, and social movement activists" as "play[ing] a critical role in translating ideas from the global arena down and from local arenas up" (Merry 2006b: 42). For Merry, these 'human rights translators' may be "local activists, human rights lawyers, feminist NGO leaders, academics, or a host of other people who have one foot in the transnational community and one at home" (ibid). An engagement with the work of those who have been professionally trained as language professionals, however, is absent. Similar gaps can be identified in research in sociolinguistics that has engaged with the role of languages in NGOs in light of globalisation and the commodification of language work (Codó and Garrido 2010; Duchêne and Heller 2012; Garrido 2017; Kahn and Heller 2006; Pujolar 2007).

At this specific moment in time, when NGOs are undergoing huge changes and are trying to respond to the 'crisis' in their sector, this may present an important opportunity for Translation and Interpreting Studies to engage with other disciplines. By finally shedding off its linguistic and literary bias and contributing to debates on development, empowerment, and NGOs, TIS could start contributing to debates in other disciplines that concern phenomena in "carrying over" in many different ways (Marais 2014: 207). As pointed out in the anthropological contributions just mentioned, translation is still very often conceptualised as a process of conveying meaning and accuracy and for that reason tends to be overlooked or discounted as an important factor of communication processes. Translation and Interpreting Studies has an important role to play in sharing its understanding of translation and interpreting as social activities, and as a site of struggle that is occupied by many different actors who hold different power positions and who are bound to different cultural and institutional ideologies. 
This is the author accepted manuscript of the article by Wine Tesseur (2018) 'Researching translation and interpreting in Non-Governmental Organisations', Translation Spaces 7(1): 1-19, which has been published in final form at https://doi.org/10.1075/ts.00001.tes. This article is under copyright and the publisher should be contacted for permission to re-use or reprint the material in any form.

\section{Bibliography}

Amnesty International UK. 2013. “The Global Transition Programme Roadmap.” International Issues News 26. Accessed March 20, 2018. https://www.amnesty.org.uk/files/iin_mar_2013_gtp_0.pdf.

Antonini, Rachele, Letizia Cirillo, Linda Rossato, and Ira Torresi (eds). 2017. Non-Professional Interpreting and Translation: State of the Art and Future of an Emerging Field of Research. Amsterdam and Philadelphia: John Benjamins.

Arranz de la Torre, Violeta. 2001. "Léxico Y Tenor En Documentos de ONG. Estudio de Un Caso ‘Híbrido’ Entre Las Convenciones Españolas Y Británicas: CUDECA.” Puentes 4: 43-54.

Baker, Mona. 2006. "Translation and Activism: Emerging Patterns of Narrative Community.” The Massachusetts Review 47 (3): 462-84.

Baker, Mona. 2009. "Resisting State Terror: Theorizing Communities of Activist Translators and Interpreters." In Globalization, Political Violence and Translation, edited by Esperanza Bielsa and Christopher W. Hughes, 222-42. Basingstoke and New York: Palgrave Macmillan.

Banks, Nicola, David Hulme, and Michael Edwards. 2015. "NGOs, States, and Donors Revisited: Still Too Close for Comfort?" World Development 66: 707-18.

Bass, Stephen, and Barry Dalal-Clayton. 2002. Sustainable Development Strategies: A Resource Book. London: Routledge.

Boéri, Julie, and Carol Maier (eds). 2010. Translation/Interpreting and Social Activism / Compromiso Social Y Traducción/Interpretación. Granada: ECOS.

Bond. 2015a. Fast Forward: The Changing Role of UK-Based INGOs. London: Bond. Accessed March 20, 2018. https://www.bond.org.uk/resources/fast-forward.

Bond. 2015b. Tomorrow's World: How Might Megatrends in Development Affect the Future Roles of UK-Based INGOs? London: Bond. Accessed March 20, 2018. https://www.bond.org.uk/resources/tomorrows-world.

Bujra, Janet. 2006. "Lost in Translation? The Use of Interpreters in Fieldwork.” In Doing Development Research, edited by Vandana Desai and Robert B Potter, 172-79. London: Sage. Byanyima, Winnie. 2015. "Oxfam International Signs Historic Deal to Move to Nairobi, Kenya." Oxfam General Blog Channel. Accessed March 20, 2018. http://oxf.am/Z2SW. 
This is the author accepted manuscript of the article by Wine Tesseur (2018) 'Researching translation and interpreting in Non-Governmental Organisations', Translation Spaces 7(1): 1-19, which has been published in final form at https://doi.org/10.1075/ts.00001.tes. This article is under copyright and the publisher should be contacted for permission to re-use or reprint the material in any form.

Cao, Deborah, and Xingmin Zhao. 2008. "Translation at the United Nations as Specialized

Translation." Journal of Specialised Translation 9: 39-54.

Carolei, Domenico. 2018. "How Is Oxfam Being Held Accountable over the Haiti Scandal?" London School of Economics and Political Science Blog. Accessed March 20, 2018.

http://blogs.lse.ac.uk/politicsandpolicy/how-is-oxfam-being-held-accountable-over-the-haitiscandal/.

Castells, Manuel. 2000. The Rise of the Network Society. The Information Age: Economy, Society and Culture, Volume 1. $2^{\text {nd }}$ ed. Malden; Oxford: Blackwell.

Chambers, Robert. 1983. Rural Development: Putting The Last First. London: Longman.

Chambers, Robert. 1997. Whose Reality Counts? Putting The First Last. London: ITDG Publishing.

CIVICUS. 2017. State of Civil Society Report. Accessed March 20, 2018.

https://www.civicus.org/index.php/state-of-civil-society-report-2017.

Codó, Eva, and Maria Rosa Garrido. 2010. "Ideologies and Practices of Multilingualism in Bureaucratic and Legal Advice Encounters.” Sociolinguistic Studies 4 (2): 297-332.

Cornwall, Andrea, and Eade, Deborah. (eds). (2010). Deconstructing Development Discourse: Buzzwords and Fuzzwords. Rugby: Practical Action Publishing with Oxfam GB.

Crack, Angela. 2014. Do NGOs Need a Languages Policy? Accessed March 20, 2018. https://www.intrac.org/resources/ngos-need-languages-policy/.

Crack, Angela. 2018. "The Oxfam Scandal Has Taught Us There Is No Reward for Honest Charities.” The Guardian, March 16. Accessed March 20, 2018. https://www.theguardian.com/voluntarysector-network/2018/mar/16/government-donors-reward-honest-charities-oxfam.

Crack, Angela Maria. 2013. "Language, Listening and Learning: Critically Reflective Accountability for INGOs.” International Review of Administrative Sciences 79 (4): 809-28.

Cronin, Michael. 2003. Translation and Globalization. London and New York: Routledge.

Davies, Tom. 2014. NGOs: A New History of Transnational Civil Society. New York: Oxford University Press.

Dijkzeul, Dennis. 2008. "Transnational Humanitarian NGOs? A Progress Report.” In Rethinking Transnationalism: The Meso-Link of Organisations, edited by Ludger Pries, 81-103. Abingdon: Routledge. 
This is the author accepted manuscript of the article by Wine Tesseur (2018) 'Researching translation and interpreting in Non-Governmental Organisations', Translation Spaces 7(1): 1-19, which has been published in final form at https://doi.org/10.1075/ts.00001.tes. This article is under copyright and the publisher should be contacted for permission to re-use or reprint the material in any form.

Duchêne, Alexandre, and Monica Heller (eds). 2012. Language in Late Capitalism: Pride and Profit.

New York and Abingdon: Routledge.

Evrin, Feyza, and Bernd Meyer (eds). 2016. Non-Professional Interpreting and Translation:

Translational Cultures in Focus. Special Issue of The European Journal of Applied Linguistics 4 (1).

Fierke, Karin Marie. 2003. "Breaking the Silence: Language and Method in International Relations." In Language, Agency, and Politics in a Constructed World, edited by Francois Debrix, 66-86. Abingdon and New York: Routledge.

Footitt, Hilary. 2017. "International Aid and Development: Hearing Multilingualism, Learning from Intercultural Encounters in the History of OxfamGB." Language and Intercultural Communication 17 (4): 518-33.

Footitt, Hilary, and Michael Kelly (eds). 2012. Languages at War: Policies and Practices of Language Contacts in Conflict. Basingstoke: Palgrave Macmillan.

Fowler, Alan, and Chiku Malunga (eds). 2010. NGO Management: The Earthscan Companion. London: Earthscan.

Gal, Susan, Julia Kowalski, and Erin Moore. 2015. "Rethinking Translation in Feminist NGOs: Rights and Empowerment Across Borders.” Social Politics 22 (4): 610-35.

Gambier, Yves. 2007. “Réseaux de Traducteurs/interprètes Bénévoles.” META 52 (4): 658-72.

Garrido, Maria Rosa. 2017. "Multilingualism and Cosmopolitanism in the Construction of a Humanitarian Elite.” Social Semiotics 27 (3): 359-69.

Ghandour-Demiri, Nada. 2017. Language and Comprehension Barriers in Greece's Migration Crisis. Translators Without Borders.

Guidère, Mathieu (ed). 2010. Traduction et Médiation Humanitaire. Paris: Le Manuscrit.

Guidère, Mathieu. 2011. "La Médiation Humanitaire Multilingue : Un Discours Pour La Paix." Revue Française de Linguistique Appliquée XVI (1): 51-62.

Guillaume, Astrid. 2010. “La Traduction Au Service Des Ong.” Hermès 56 (1): 83-89.

Hayman, Rachel, Sophie King, Tiina Kontinen, and Lata Narayanaswamy (eds). 2016. Negotiating Knowledge: Evidence and Experience in Development NGOs. Rugby: Practical Action Publishing. 
This is the author accepted manuscript of the article by Wine Tesseur (2018) 'Researching translation and interpreting in Non-Governmental Organisations', Translation Spaces 7(1): 1-19, which has been published in final form at https://doi.org/10.1075/ts.00001.tes. This article is under copyright and the publisher should be contacted for permission to re-use or reprint the material in any form.

Hilhorst, Dorothea. 2018. “Aid Agencies Can't Police Themselves. It's Time for a Change.” IRIN

News. Accessed March 20, 2018. http://www.irinnews.org/opinion/2018/02/22/aid-agenciescan-t-police-themselves-it-s-time-change.

Holcombe, Sarah. 2015. "The Revealing Processes of Interpretation: Translating Human Rights Principles into Pintupi-Luritja.” TAJA: The Australian Journal of Anthropology 26: 428-41.

Kahn, Emmanuel, and Monica Heller. 2006. "Idéologies et Pratiques Du Multilinguisme Au Québec. Luttes et Mutations Dans Un Site de La Nouvelle Économie.” Langage et Société 118 (4): 4363.

Kang, Ji-Hae. 2014. "Institutions Translated: Discourse, Identity and Power in Institutional Mediation." Perspectives 22 (4): 469-78.

Koskinen, Kaisa. 2008. Translating Institutions: An Ethnographic Study of EU Translation. Manchester: St. Jerome.

Lehtovaara, Heini. 2009. Working in Four Official Languages: The Perceptions of OGB Employees on the Role of Language in Internal Communication. Masters Thesis, Helsinki School of Economics.

Lewis, David. 2014. Non-Governmental Organizations, Management and Development. 3rd ed. Abingdon and New York: Routledge.

Maclean, Kate. 2007. “Translation in Cross-Cultural Research: An Example from Bolivia.” Development in Practice 17 (6): 784-90.

Marais, Kobus. 2014. Translation Theory and Development Studies: A Complexity Theory Approach. New York \& Abingdon: Routledge.

McCall, Elizabeth. 2011. Communciation for Development: Strenthening the Effectiveness of the United Nations. New York: United Nations Development Programme.

McGann, James, and Mary Johnstone. 2005. "The Power Shift and the NGO Credibility Crisis.” The Brown Journal of World Affairs 11 (2): 159-72.

McGrew, Anthony, and David Held (eds). 2002. Governing Globalization: Power, Authority and Global Governance. Cambridge: Polity Press.

Merry, Sally Engle. 2006a. Human Rights and Gender Violence: Translating International Law into Local Justice. Chicago: Chicago Series in Law and Society.

Merry, Sally Engle. 2006b. "Transnational Human Rights and Local Activism: Mapping the Middle.” 
This is the author accepted manuscript of the article by Wine Tesseur (2018) 'Researching translation and interpreting in Non-Governmental Organisations', Translation Spaces 7(1): 1-19, which has been published in final form at https://doi.org/10.1075/ts.00001.tes. This article is under copyright and the publisher should be contacted for permission to re-use or reprint the material in

American Anthropologist 108 (1): 38-51. any form.

Merry, Sally Engle, and Summer Wood. 2015. "Quantification and the Paradox of Measurement." Current Anthropology 56 (2): 205-29.

Meylaerts, Reine. 2017. "Studying Language and Translation Policies in Belgium: What Can We Learn from a Complexity Theory Approach?” Parallèles 29 (1): 45-59.

Moorehead, Joanna, and Joe Sandler Clark. 2015. "Big NGOs Prepare to Move South, but Will It Make a Difference?” The Guardian, November 16. Accessed March 20, 2018.

http://www.theguardian.com/global-development-professionals-network/2015/nov/16/big-ngosafrica-amnesty-oxfam-actionaid.

Pérez-González, Luis, and Şebnem Susam-Saraeva (eds). 2012. Non-Professionals Translating and Interpreting. Participatory and Engaged Perspectives. Special Issue of The Translator 18 (2).

Pujolar, Joan. 2007. "Bilingualism and the Nation-State in the Post-National Era." In Bilingualism: A Social Approach, 71-95. London and New York: Palgrave Macmillan.

Pym, Anthony. 2008. "Translation vs. Language Learning in International Institutions: Explaining the Diversity Paradox." Cultus: The Journal of Intercultural Mediation and Communication 1 (1): $70-83$.

Rampton, Ben, Janet Maybin, and Celia Roberts. 2015. "Theory and Method in Linguistic Ethnography." In Linguistic Ethnography: Interdisciplinary Explorations, edited by Julia Snell, Sara Shaw, and Fiona Copland, 14-50. London: Palgrave Macmillan.

Schäffner, Christina. 2001. "Translation and the EU: Conditions and Consequences." Perspectives 9 (4): 247-61.

Schäffner, Christina, Krzysztof Kredens, and Yvonne Fowler (eds). 2013. "Interpreting in a Changing Landscape: Challenges for Research and Practice.” In Interpreting in a Changing Landscape: Selected Papers from Critical Link 6, 1-11. Amsterdam and Philadelphia: John Benjamins.

Schäffner, Christina, Luciana Sabina Tcaciuc, and Wine Tesseur. 2014. "Translation Practices in Political Institutions: A Comparison of National, Supranational, and Non-Governmental Organisations." Perspectives 22 (4): 493-510.

Smedley, Tim. 2014. "Shifting Sands : The Changing Landscape for International NGOs." The Guardian, March 28. Accessed March 20, 2018. http://www.theguardian.com/globaldevelopment-professionals-network/2014/mar/28/internaitonal-ngos-funding-network. 
This is the author accepted manuscript of the article by Wine Tesseur (2018) 'Researching translation and interpreting in Non-Governmental Organisations', Translation Spaces 7(1): 1-19, which has been published in final form at https://doi.org/10.1075/ts.00001.tes. This article is under copyright and the publisher should be contacted for permission to re-use or reprint the material in any form.

Suzuki, Naoki. 1998. Inside NGOs: Managing Conflicts Between Headquarters and the Field Offices in Non-Governmental Organizations. London: Intermediate Technology Publications.

Taibi, Mustapha, and Uldis Ozolins. 2016. Community Translation. London: Bloomsbury Academic.

Tcaciuc, Luciana Sabina, and Vladislav Mackevic. 2017. “Translators' Agency in Translating Economic Metaphors in European Union Institutions: The Case of the European Central Bank Translators' Agency in Translating Economic Metaphors in European Union Institutions : The Case of the European Central." Perspectives 25 (3): 417-433.

Tesseur, Wine. 2014. Transformation through Translation: Translation Policies at Amnesty International. Unpublished PhD thesis, Aston University.

Tesseur, Wine. 2015. Report: Round Table Translation Policies at NGOs. Accessed April 3, 2018. https://www.reading.ac.uk/web/files/modern-languages-and-european-studies/Round-table-onTranslation-policies-at-NGOs-Report.pdf.

Tesseur, Wine. 2017a. "Incorporating Translation into Sociolinguistic Research: Translation Policy in an International Non-Governmental Organisation.” Journal of Sociolinguistics 21 (5): 629-49.

Tesseur, Wine. 2017b. "The Translation Challenges of INGOs: Professional and Non-Professional Translation at Amnesty International.” Translation Spaces 6 (2): 209 - 229.

Tipton, Rebecca. 2017. "Interpreting-as-Conflict: PSIT in Third Sector Organisations and the Impact of Third Way Politics.” In Ideology, Ethics and Policy Development in Public Service Interpreting and Translation, 38-62. Clevedon: Multilingual Matters.

Tosi, Arturo, ed. 2003. Crossing Barriers and Bridging Cultures: The Challenges of Multilingual Translation for the European Union. Clevedon: Multilingual Matters.

Union of International Associations (ed). 2014. Yearbook of International Organizations 2014-2015. Volume 5: Statistics, Visualizations and Patterns. Leiden and Boston: Brill and Martinus Nijhoff.

United Nations. 2015. Transforming Our World: The 2030 Agenda for Sustainable Development. Resolution adopted by the General Assembly on 25 September 2015. Index: A/RES/70/1. Valero-Garcés, Carmen, and Rebecca Tipton (eds). 2017. Ideology, Ethics and Policy Development in Public Service Interpreting and Translation. Clevedon: Multilingual Matters.

Valero Garcés, Carmen, and Lenuta Cata. 2006. “Acción Y Voluntariado. Las ONG Y Los Servicios de Traducción E Interpretación.” Revista Española de Lingüística Aplicada 19: 49-60. 
This is the author accepted manuscript of the article by Wine Tesseur (2018) 'Researching translation and interpreting in Non-Governmental Organisations', Translation Spaces 7(1): 1-19, which has been published in final form at https://doi.org/10.1075/ts.00001.tes. This article is under copyright and the publisher should be contacted for permission to re-use or reprint the material in any form.

Wallace, Tina, Lisa Bornstein, and Jennifer Chapman. 2007. The Aid Chain: Coercion and

Commitment in Development NGOs. Rugby: Practical Action Publishing.

Willetts, Peter. 2011. Non-Governmental Organizations in World Politics. Abingdon, Oxon:

Routledge.

World Bank. 1998. World Development Report 1998/1999: Knowledge for Development. Oxford:

Oxford University Press. 
This is the author accepted manuscript of the article by Wine Tesseur (2018) 'Researching translation and interpreting in Non-Governmental Organisations', Translation Spaces 7(1): 1-19, which has been published in final form at https://doi.org/10.1075/ts.00001.tes. This article is under copyright and the publisher should be contacted for permission to re-use or reprint the material in

\section{Author information} any form.

Wine Tesseur

University of Reading, UK

ORCID: http://orcid.org/0000-0003-4882-3623

E-mail: winetesseur@gmail.com

Postal address: Apartment 307 Islington Gates, 4 Fleet Street, Birmingham, B3 1JH, Birmingham 